\title{
Distinct Forms of Lactate Dehydrogenase Purified from Ethanol- and Lactate-producing Cells of Clostridium thermohydrosulfuricum
}

\author{
By MARJA TURUNEN, * ELKE PARKKINEN, JOHN LONDESBOROUGH \\ AND MATTI KORHOLA \\ Research Laboratories of the Finnish State Alcohol Company, Alko Ltd, POB 350, \\ SF-00101 Helsinki, Finland
}

(Received 16 February 1987; revised I May 1987)

\begin{abstract}
Thermostable lactate dehydrogenases (EC 1.1.1.27) were purified to homogeneity from Clostridium thermohydrosulfuricum cells grown on starch and producing mainly ethanol $\left(\mathrm{LDH}_{\mathrm{E}}\right)$ and from cells grown on sucrose and producing mainly lactic acid $\left(\mathrm{LDH}_{\mathrm{L}}\right)$, and were found to be distinct isoenzymes. The two enzymes both had native $M_{\mathrm{r}}$ values close to $145 \times 10^{3}$, but slightly different subunits with $M_{\mathrm{r}}$ values about $37 \times 10^{3}$. $\mathrm{LDH}_{\mathrm{L}}$ dissociated into subunits more readily. The isoelectric points were 5.0 for $\mathrm{LDH}_{\mathrm{L}}$ and 5.2 for $\mathrm{LDH}_{\mathrm{E}}$. The catalytic activity of $\mathrm{LDH}_{\mathrm{E}}$ had an almost absolute requirement for fructose 1,6-bisphosphate (FBP) at all temperatures (22-fold activation with $K_{1 / 2} 12 \mu \mathrm{M}$-FBP at $\left.65^{\circ} \mathrm{C}, \mathrm{pH} 6.0\right) . \mathrm{LDH}_{\mathrm{L}}$ was activated by FBP only at temperatures over $40^{\circ} \mathrm{C}$ (5-fold activation with $K_{1 / 2} 80 \mu \mathrm{M}-\mathrm{FBP}$ at $\left.65^{\circ} \mathrm{C}, \mathrm{pH} 6 \cdot 0\right)$. For both enzymes the optimum temperature for pyruvate reduction in the presence of $1 \mathrm{mM}$-FBP was $70{ }^{\circ} \mathrm{C}$ and the $\mathrm{pH}$ optimum at $65^{\circ} \mathrm{C}$ was sharp and at 5.5-6.0. FBP lowered the apparent $K_{\mathrm{m}}$ of $\mathrm{LDH}_{\mathrm{L}}$ for pyruvate. At $50 \mu \mathrm{M}-\mathrm{FBP}$ both enzymes showed a positive co-operative dependence on NADH.
\end{abstract}

\section{INTRODUCTION}

Clostridium thermohydrosulfuricum is one of the thermophilic saccharolytic species that are of considerable interest for industrial ethanol production. It ferments starch, cellobiose, sucrose and a wide variety of hexoses and pentoses yielding ethanol, carbon dioxide, lactate, acetate and hydrogen. The production of ethanol in $C$. thermohydrosulfuricum is influenced by substrate type, substrate concentration and $\mathrm{pH}$ (Carreira et al., 1983; Parkkinen \& Korhola, 1984). C. thermohydrosulfuricum catabolizes glucose via the Embden-Meyerhof-Parnas pathway (Zeikus et al., 1981), and contains both $\mathrm{NAD}^{+}$- and NADP ${ }^{+}$-dependent alcohol dehydrogenase (ADH) activities (Lamed \& Zeikus, 1981) and FBP-activated LDH (Hyun et al., 1985; Germain et al., 1986). The regulation of these catabolic pathways at the enzyme level is poorly understood.

In the present work we studied the activities of LDH and ADH during glucose, sucrose and starch fermentations to investigate further why sucrose fermentations yield sometimes ethanol and sometimes lactic acid as the main product. We found that ethanol-producing and lactateproducing cells contained distinct isoenzymes of $\mathrm{LDH}$. Both isoenzymes were purified to homogeneity and some of their kinetic characteristics were examined.

\section{METHODS}

Bacterial strain. Clostridium thermohydrosulfuricum strain E-101-69 was obtained from F. Hollaus (Sugar Research Institute, Fuchsenbigl, Austria).

Cultivation conditions. Cells were grown in a complex medium containing $\left(\mathrm{g} \mathrm{l}^{-1}\right)$ tryptone (Difco, 10), meat extract (Oxoid, 5), yeast extract (Difco, 5), $\mathrm{K}_{2} \mathrm{HPO}_{4}(1), \mathrm{FeSO}_{4} \cdot 7 \mathrm{H}_{2} \mathrm{O}(0 \cdot 02), \mathrm{MgSO}_{4} \cdot 7 \mathrm{H}_{2} \mathrm{O}(0 \cdot 1)$ and either

Abbreviations: ADH, alcohol dehydrogenase; FBP, fructose 1,6-bisphosphate; LDH, lactate dehydrogenase. 
glucose, sucrose or starch (30). The starch was from Merck (starch soluble, GR 1252). The inocula were grown in $100 \mathrm{ml}$ of medium containing glucose $\left(10 \mathrm{~g} \mathrm{t}^{-1}\right)$ in $100 \mathrm{ml}$ flasks enclosed in anaerobic jars at $68^{\circ} \mathrm{C}$. The fermentations were done in fermentors with working volumes in 101 (Bioengineering) or 1.51 (Biostat M, B. Braun). The medium was inoculated with $5 \%(\mathrm{v} / \mathrm{v})$ of $12 \mathrm{~h}$ (late exponential phase) flask culture. Fermentor cultures were maintained with constant stirring (100 r.p.m.) and continuous gassing with oxygen-free nitrogen (11 $1^{-1} \mathrm{~h}^{-1}$ ) at $68^{\circ} \mathrm{C}$. The $\mathrm{pH}$ was kept at the desired value, usually 6.8 , with $5 \mathrm{M}-\mathrm{KOH}$. Growth was monitored by using a Klett-Summerson colorimeter.

Measurement of substrates and products. Glucose, sucrose, L-lactic acid and acetic acid were determined enzymically with Boehringer Test Combination kits after centrifugation of the media at $10000 \mathrm{~g}$ for $10 \mathrm{~min}$. Starch and ethanol were determined as described by Parkkinen (1986).

Preparation of cell-free extracts. Cells were harvested from 1 to 21 of culture medium by centrifugation at $8000 \mathrm{~g}$ for $10 \mathrm{~min}$ at $4{ }^{\circ} \mathrm{C}$, washed once with $25 \mathrm{mM}$-Tris/ $\mathrm{HCl}(\mathrm{pH} 7 \cdot 4)$ containing $2 \mathrm{~mm}$-dithiothreitol and $0 \cdot 1 \mathrm{mM}$ EDTA or with $50 \mathrm{~mm}$-imidazole/ $\mathrm{HCl}(\mathrm{pH} \mathrm{6.1)}$ containing $0 \cdot 1 \mathrm{~mm}$-EDTA (IE buffer, used for enzyme purification), suspended in the same buffer $\left[2 \mathrm{ml}(\mathrm{g} \text { wet wt cells })^{-1}\right]$ and stored at $-20^{\circ} \mathrm{C}$. The cells were ruptured by two passes through an X-press (Biox) at $-25^{\circ} \mathrm{C}$ and then centrifuged at $25000 \mathrm{~g}$ for $45 \mathrm{~min}$ at $4{ }^{\circ} \mathrm{C}$. Protein was estimated by the method of Bradford (1976) with bovine serum albumin as standard.

Enzyme purification. Steps were done at 0 to $10^{\circ} \mathrm{C}$ unless otherwise stated. Yields (U) and specific activities [ $\mathrm{U}$ (mg protein $)^{-1}$ ] measured at $40^{\circ} \mathrm{C}$ are shown for preparations of $\mathrm{LDH}_{\mathrm{L}}$ from $6.6 \mathrm{~g}$ wet wt cells from a sucrose fermentation that produced $16 \mathrm{~g}$ lactic acid $\mathrm{l}^{-1}$ and $0.6 \mathrm{~g}$ ethanol $\mathrm{l}^{-1}$, and of $\mathrm{LDH}_{\mathrm{E}}$ from $25 \mathrm{~g}$ wet wt cells from a starch fermentation that produced $0.6 \mathrm{~g}$ lactic acid $1^{-1}$ and $10 \mathrm{~g}$ ethanol $\mathrm{l}^{-1}$.

Streptomycin sulphate precipitation. The cell-free extracts $\left(\mathrm{LDH}_{\mathrm{L}} 4100 \mathrm{U}\right.$ at $34 \mathrm{U} \mathrm{mg}^{-1} ; \mathrm{LDH}_{\mathrm{E}} 1600 \mathrm{U}$ at $2.8 \mathrm{U}$ $\mathrm{mg}^{-1}$ ) were mixed with $1 \mathrm{ml}$ streptomycin sulphate $\left(25 \mathrm{mg} \mathrm{ml}^{-1}\right.$ in IE buffer) per $100 \mathrm{mg}$ protein, and after $30 \mathrm{~min}$ centrifuged at $17000 \mathrm{~g}$ for $30 \mathrm{~min}$. Streptomycin sulphate was removed from the supernatant by ultrafiltration using an Amicon PM 10 membrane. $\left(\mathrm{LDH}_{\mathrm{L}} 3100 \mathrm{U}\right.$ at $39 \mathrm{U} \mathrm{mg}^{-1} ; \mathrm{LDH}_{\mathrm{E}} 1800 \mathrm{U}$ at $\left.4.0 \mathrm{U} \mathrm{mg}^{-1}\right)$.

Affinity chromatography. The supernatant (about $13 \mathrm{ml}$ ) was applied to a Blue Sepharose CL-6B column $(1.5 \mathrm{~cm} \times 30 \mathrm{~cm})$ equilibrated with IE buffer. The column was washed with IE buffer and then developed with a linear gradient containing 0 to $5 \mathrm{~mm}-\mathrm{NADH}$ in $100 \mathrm{ml}$ IE buffer at a flow of $4.6 \mathrm{ml} \mathrm{h}^{-1}$. Pooled active fractions were concentrated to about $2 \mathrm{ml}$ and the buffer was changed to $25 \mathrm{mM}$-bis-Tris/ $\mathrm{HCl}(\mathrm{pH} 6.0$ ) by using a Centricon microconcentrator (cutoff 30000). ( $\mathrm{LDH}_{\mathrm{L}} 1700 \mathrm{U}$ at $560 \mathrm{U} \mathrm{mg}^{-1} ; \mathrm{LDH}_{\mathrm{E}} 850 \mathrm{U}$ at $200 \mathrm{U} \mathrm{mg} \mathrm{m}^{-1}$.)

Chromatofocusing. This was done at about $23^{\circ} \mathrm{C}$ on a Mono P HR 5/20 FPLC column (Pharmacia) equilibrated with $25 \mathrm{~mm}$-bis-Tris/ $\mathrm{HCl}$ ( $\mathrm{pH} \mathrm{6.0)}$. Proteins were eluted at $30 \mathrm{ml} \mathrm{h}^{-1}$ with a buffer (adjusted to $\mathrm{pH} 3.3$ with $\mathrm{HCl}$ ) containing in $100 \mathrm{ml} 5 \mathrm{ml}$ Polybuffer 74 and $1 \mathrm{ml}$ Pharmalyte 2.5-5 (Pharmacia). The most active fractions were pooled. For $\mathrm{LDH}_{\mathrm{E}}$ a second run on Mono $\mathrm{P}$ was done with a $\mathrm{pH}$ gradient of 5.6-3.9. ( $\mathrm{LDH}_{\mathrm{L}} 1010 \mathrm{U}$ at $590 \mathrm{U} \mathrm{mg}^{-1}$; $\mathrm{LDH}_{\mathrm{E}} 240 \mathrm{U}$ at $420 \mathrm{U} \mathrm{mg}^{-1}$.)

Gel filtration. The pooled fractions were transferred to $20 \mathrm{mM}$-sodium phosphate (pH 6.8 ) containing $180 \mathrm{mM}$ $\mathrm{NaCl}$ by using a Centricon- 30 microconcentrator and $200 \mu \mathrm{l}$ portions were run through a calibrated Superose $12 \mathrm{HR} 10 / 30 \mathrm{FPLC}$ column at about $23^{\circ} \mathrm{C}$ and $30 \mathrm{ml} \mathrm{h}^{-1}$. $\left(\mathrm{LDH}_{\mathrm{L}} 620 \mathrm{U}\right.$ at $520 \mathrm{U} \mathrm{mg}^{-1} ; \mathrm{LDH}_{\mathrm{E}} 180 \mathrm{U}$ at $700 \mathrm{U}$ $\mathrm{mg}^{-1}$.)

Enzyme assays. Standard enzyme activities were measured at $40^{\circ} \mathrm{C}$ by the spectrophotometric methods used by Lamed \& Zeikus (1980) with slight modifications. The assays were done in the presence of air with the exception of $\mathrm{NAD}^{+}$-dependent ADH activity which was determined anaerobically (reaction mixtures were flushed with nitrogen before starting the reaction). NADH oxidase activity was negligible with the amounts of crude extract used. Assay mixtures for ADH (EC 1.1.1.1 and EC 1.1.1.2) contained in $3 \mathrm{ml}: 0 \cdot 1 \mathrm{M}-\mathrm{Tris} / \mathrm{HCl}$ (pH 7.8), $2 \mathrm{mM}$ dithiothreitol, $0.25 \mathrm{~mm}-\mathrm{NAD}(\mathrm{P}) \mathrm{H}$ and $25 \mathrm{~mm}$-acetaldehyde. Standard assay mixture for NAD ${ }^{+}$-dependent LDH (EC 1.1.1.27) contained in $3 \mathrm{ml}: 0.1 \mathrm{M}$-imidazole/ $\mathrm{HCl}\left(\mathrm{pH} 6.4\right.$ at $\left.40^{\circ} \mathrm{C}\right), 0.25 \mathrm{~mm}-\mathrm{NADH}, 10 \mathrm{~mm}$-sodium pyruvate and, when indicated, $1 \mathrm{mM}-\mathrm{FBP}$. The reaction was started by adding pyruvate. The assay mixture for the oxidation of lactate contained in $3 \mathrm{ml}: 100 \mathrm{~mm}$-imidazole/ $\mathrm{HCl}(\mathrm{pH} 8.0), 0.75 \mathrm{mM}-\mathrm{NAD}^{+}, 100 \mathrm{~mm}-\mathrm{lithium} \mathrm{L-}$ lactate or lithium D-lactate with or without $1 \mathrm{mM}$-FBP. One unit (U) of each enzyme catalyses the oxidation of $1 \mu \mathrm{mol}$ NAD(P)H $\mathrm{min}^{-1}$.

Electrophoresis and gel staining. Discontinuous polyacrylamide gel electrophoresis of native proteins was done at $10{ }^{\circ} \mathrm{C}$ using the buffer system described by Davis (1964) with $12.5 \%(\mathrm{w} / \mathrm{v})$ polyacrylamide in the separation gel. After electrophoresis $\mathrm{NAD}^{+}$-dependent $\mathrm{LDH}$ activity was located by modifications of methods described by Garvie (1969). In the direct staining method the gel was incubated for $15 \mathrm{~min}$ at $50^{\circ} \mathrm{C}$ in a solution containing $50 \mathrm{mg} \mathrm{NAD}+, 10 \mathrm{mg}$ nitro blue tetrazolium, $2 \mathrm{mg}$ phenazine methosulphate and $2 \mathrm{mmol}$ lithium D-lactate or $4 \mathrm{mmol}$ sodium DL-lactate in $100 \mathrm{ml} 0.1 \mathrm{M}-\mathrm{Tris} / \mathrm{HCl}(\mathrm{pH} 8.3)$. In the indirect method the gel was placed in a solution containing $100 \mathrm{mg} \mathrm{NADH}, 1 \mathrm{mmol}$ pyruvate and (where indicated) $0.1 \mathrm{mmol}$ FBP in $100 \mathrm{ml} 0.1 \mathrm{M}$ imidazole $/ \mathrm{HCl}\left(\mathrm{pH} \mathrm{6.2)}\right.$ ) for $15 \mathrm{~min}$ at $50{ }^{\circ} \mathrm{C}$. The reaction mixture was removed and the gel stained in a solution containing $50 \mathrm{mg}$ nitro blue tetrazolium and $4 \mathrm{mg}$ phenazine methosulphate in $100 \mathrm{ml} 0.1 \mathrm{M}$-imidazole $/ \mathrm{HCl}$ (pH 6.2). 
Gel electrophoresis of native proteins and $M_{\mathrm{r}}$ standards (Pharmacia) on 4-30\% $(\mathrm{w} / \mathrm{v})$ polyacrylamide gradients was for 2600 volt hours at $10^{\circ} \mathrm{C}$ on PAA $4 / 30$ gels (Pharmacia) in $0.09 \mathrm{M}$-Tris, $0.08 \mathrm{M}$-boric acid, $0.0025 \mathrm{M}$ $\mathrm{Na}_{2}$ EDTA (pH 8.4). The gels were fixed with $10 \%(\mathrm{w} / \mathrm{v})$ sulphosalicylic acid and stained with Coomassie blue.

PAGE in the presence of SDS was done by the method of Laemmli (1970) with a linear gradient from $13 \%$ to $7 \%$ $(\mathrm{w} / \mathrm{v})$ acrylamide in the separator gel and a $3.75 \%(\mathrm{w} / \mathrm{v})$ stacking gel. Gels were fixed with $50 \%(\mathrm{w} / \mathrm{v})$ trichloracetic acid and stained with Coomassie blue.

Isoelectric focusing. Isoelectric points were determined by isoelectric focusing on ready made Ampholine thinlayer gels (LKB, pH range 4.0-6.5). Protein pI standards (Pharmacia) included soybean trypsin inhibitor (4.55) and $\beta$-lactoglobulin $A(5 \cdot 20)$. The gels were run, fixed and stained according to the manufacturer's instructions.

\section{RESULTS}

\section{Fermentations and enzymes involved in pyruvate catabolism}

The mass ratio of the main fermentation products ethanol:L-lactate : acetate was always close to $10: 1: 1$ after growth on $3 \%(\mathrm{w} / \mathrm{v})$ glucose and 10:0 1:1 after growth on $3 \%(\mathrm{w} / \mathrm{v})$ soluble starch at $\mathrm{pH} 6.8$. However, after growth on $3 \%(\mathrm{w} / \mathrm{v})$ sucrose this ratio varied between $10: 0.5: 0.5$ and $0 \cdot 1: 10: 0 \cdot 1$ (data not shown). The causes of this variability during sucrose fermentations are still unclear, though some factors have been identified (Parkkinen \& Turunen, 1986). Extensive lactic acid production was followed by significant cell lysis.

Fig. 1 shows the product formation kinetics and the enzyme levels during fermentations with different carbon sources. The activity of LDH in samples from glucose and starch fermentations was increased about 10 -fold by addition of $1 \mathrm{mM}$-FBP to the reaction mixture. LDH activity was very high at the end of exponential growth on sucrose at $\mathrm{pH} 7 \cdot 2$, and in this case added FBP had little effect on the LDH activity measured at $40^{\circ} \mathrm{C}$. The activity of $\mathrm{NADP}^{+}$-linked ADH was usually about 10 -fold that of $\mathrm{NAD}^{+}$-linked $\mathrm{ADH}$. The activity of $\mathrm{NADP}^{+}$-linked $\mathrm{ADH}$ was markedly decreased during sucrose fermentation when lactic acid was the main product.

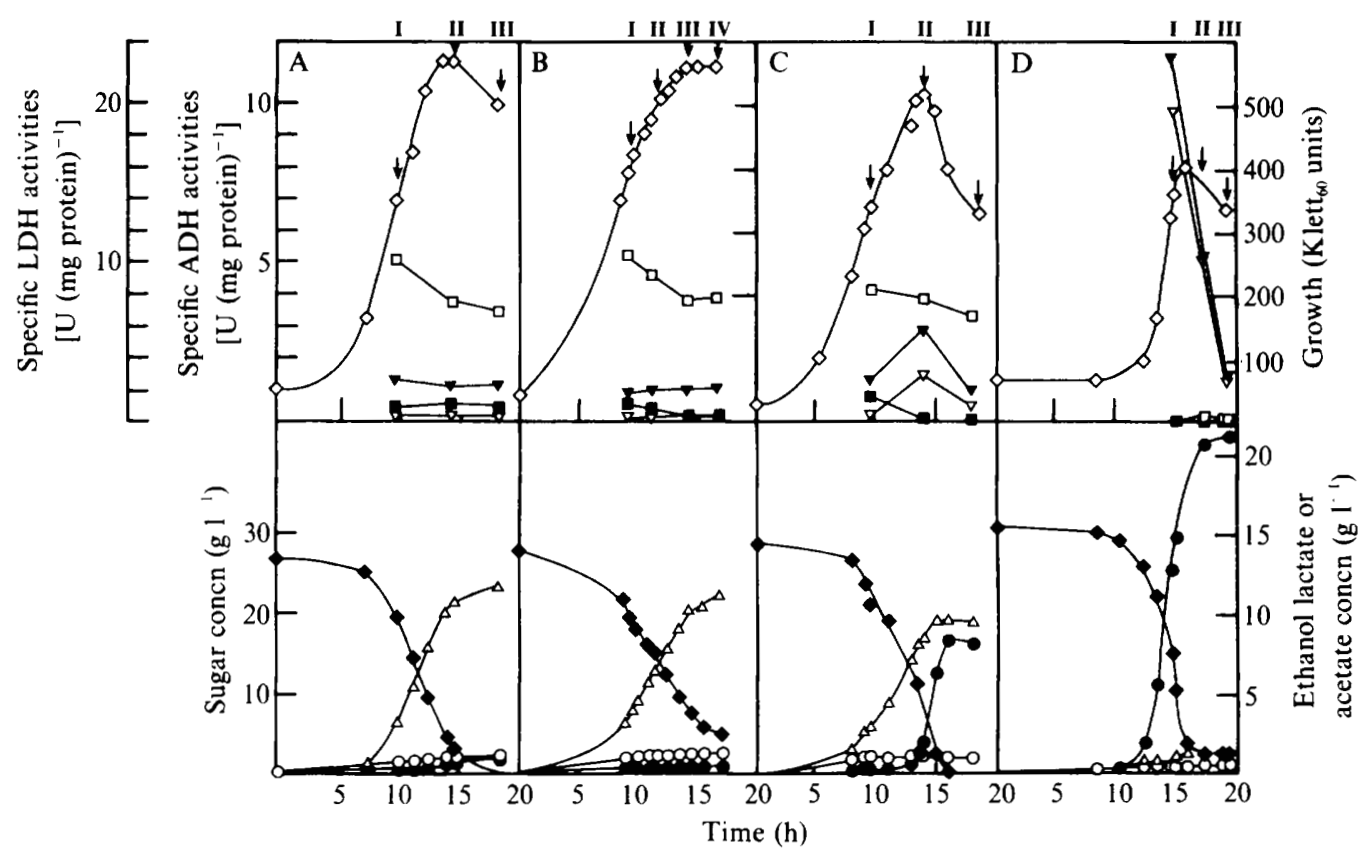

Fig. 1. Activities of $\mathrm{LDH}$ and $\mathrm{ADH}$ and kinetics of product formation during fermentations with different carbon sources. Fermentations containing $1013 \%$ glucose $\mathrm{pH} 6.8(\mathrm{~A}), 3 \%$ starch pH 6.8 (B), $3 \%$ sucrose $\mathrm{pH} 6.8(\mathrm{C})$ or $3 \%$ sucrose $\mathrm{pH} 7.2$ (D) were done as described in Methods. $\bigcirc$, L-Lactate; $\mathrm{O}$, acetate; $\triangle$, ethanol; $\nabla$, carbon source; $\diamond$, growth; $\nabla$, LDH assayed at $40^{\circ} \mathrm{C}$ with 1 mM-FBP; $\nabla$, LDH assayed at $40^{\circ} \mathrm{C}$ without added FBP; $\square$, NADP+-linked ADH; $\square$, NAD ${ }^{+}$-linked ADH. Samples for enzyme assays were taken at the points (I, II, III and IV) shown by arrows. 


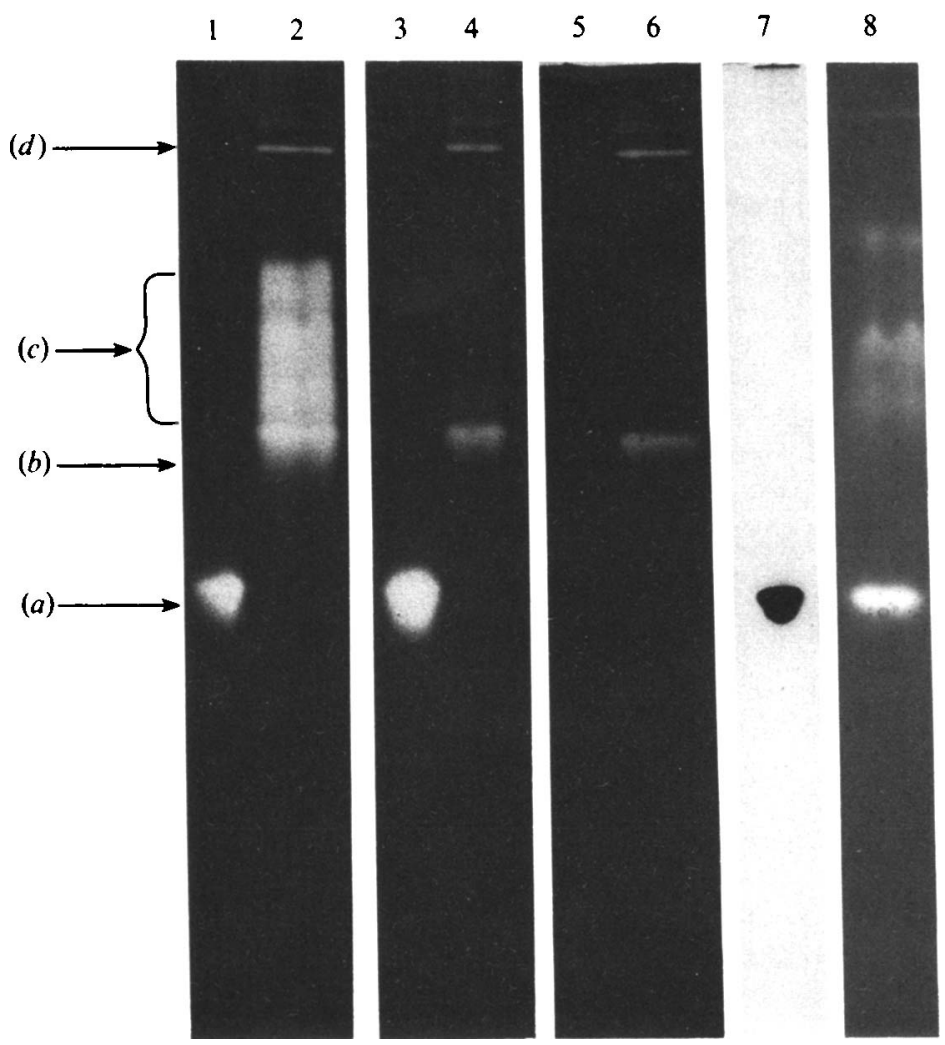

Fig. 2. Distribution of LDH activity after discontinuous PAGE of cell-free extracts. Lanes $1,3,5$ and 7, extracts of lactate-producing cells grown on sucrose (DI in Fig. 1) $(1 \cdot 1 \mu \mathrm{g}, 1 \cdot 1 \mu \mathrm{g}, 1 \cdot 1 \mu \mathrm{g}$ and $33.6 \mu \mathrm{g}$ protein respectively); lanes 2, 4 and 6, extracts of ethanol-producing cells grown on starch (BII in Fig. 1) $(15.3 \mu \mathrm{g}, 7.7 \mu \mathrm{g}$ and $15.3 \mu \mathrm{g}$ protein respectively); lane 8, extract of lactate- and ethanol-producing cells (CII in Fig. 1) $(2.8 \mu \mathrm{g}$ protein). Before electrophoresis the samples were dialysed against $25 \mathrm{~mm}$ Tris/ $\mathrm{HCl}$ (pH 7.4) containing 2 mM-dithiothreitol and 0.1 mM-EDTA. After electrophoresis the gel was cut into strips which were then stained for LDH activity as described in Methods. Lanes 1 to 6 and 8 were stained by the indirect method, lanes 1,2 and 8 with FBP, lanes 3 and 4 without FBP and lanes 5 and 6 without FBP and without pyruvate. Lane 7 was stained by the direct method with sodium DLlactate as substrate and without FBP. The origin is at the top.

After electrophoresis of dialysed cell extracts LDH activity was detected in two different areas (Fig. 2). A slow-moving broad band (c, Fig. 2) was observed only when FBP was present in the staining mixture. This band was not detected in the extract of cells grown on sucrose and producing mainly lactic acid. A faster-moving and sharper band ( $a$, Fig. 2$)$ that did not require FBP was detected only in extracts of lactate-producing cells. This band could also be detected by direct staining with DL-lactate (Fig. 2) or with L-lactate but not with D-lactate (not shown). Both LDH bands were observed during electrophoresis of extracts of sucrose-grown cells that produced ethanol and lactic acid in nearly equal amounts (lane 8, Fig. 2). The sharp bands ( $b$ and $d$, Fig. 2) that also appeared in the absence of pyruvate may be NADH oxidases.

\section{Enzyme purification}

These results suggested that $C$. thermohydrosulfuricum might contain two different LDH enzymes: $\mathrm{LDH}_{\mathrm{E}}$ during fermentations producing ethanol, and $\mathrm{LDH}_{\mathrm{L}}$ during sucrose fermentations in which lactate was the main product. To test this hypothesis, $\mathrm{LDH}$ was purified both from cells producing mainly ethanol and from cells producing mainly lactic acid (corresponding to fermentations B and D respectively in Fig. 1). 


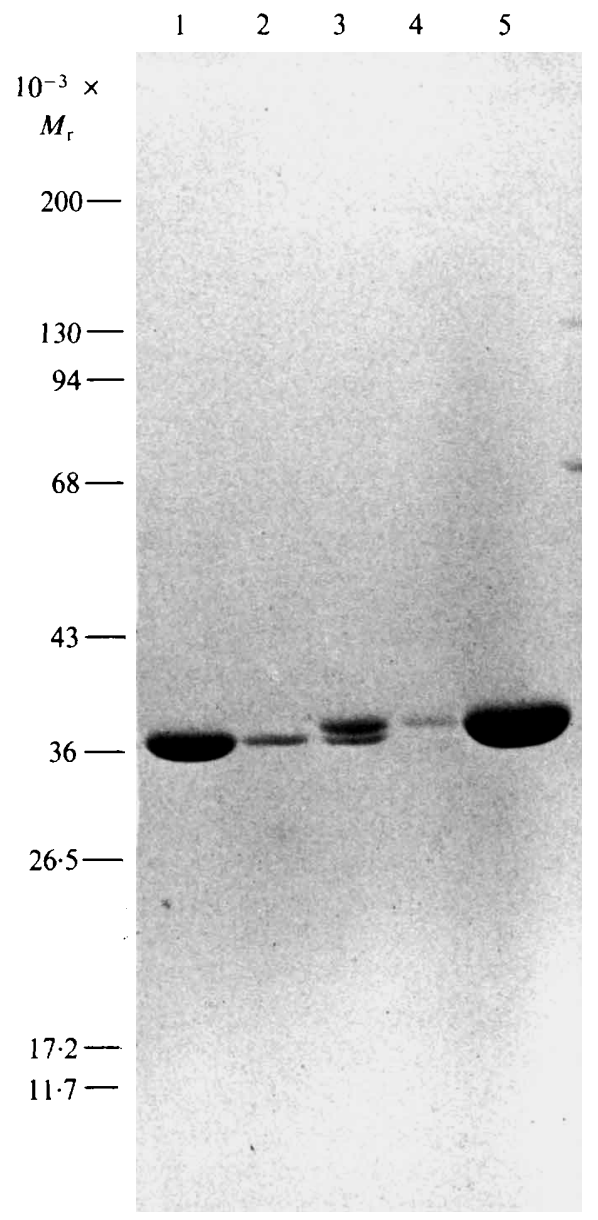

Fig. 3. SDS-PAGE of the purified LDH preparations. Lane 1, 7.1 $\mu \mathrm{gDH}_{\mathrm{E}}$; lane $2,1 \cdot 2 \mu \mathrm{g} \mathrm{LDH}_{\mathrm{E}}$; lane 3, $1.2 \mu \mathrm{g} \mathrm{LDH}$ and 2.1 $\mu \mathrm{gLH}_{\mathrm{L}}$; lane 4, 2.1 $\mu \mathrm{g} \mathrm{LDH}_{\mathrm{L}}$; lane 5, $12.6 \mu \mathrm{gLH}_{\mathrm{L}}$. Electrophoresis and gel staining were done as described in Methods. $M_{\mathrm{r}}$ standards are indicated on the left.

Representative purifications are described in Methods. Preparation of homogeneous enzyme required a 15 -fold purification from the lactate-producing cells but 250 -fold purification from ethanol-producing cells. However, LDH activity behaved similarly in both purifications. It eluted from the Blue Sepharose at about $0.5 \mathrm{~mm}-\mathrm{NADH}$. In chromatofocusing, $\mathrm{LDH}_{\mathrm{L}}$ eluted at a slightly lower $\mathrm{pH}$ (activity peak at $\mathrm{pH} 4.4$ ) than $\mathrm{LDH}_{\mathrm{E}}$ (activity peak at $\mathrm{pH} 4.7$ ). The maximum specific activities at $40{ }^{\circ} \mathrm{C}$ agreed within $15 \%$ but $\mathrm{LDH}_{\mathrm{L}}$ then lost some activity in the final gel-filtration.

\section{Physical properties of the purified enzymes}

Both enzymes exhibited native $M_{\mathrm{r}}$ values (at room temperature, pH 6.8) of $145 \times 10^{3}$ during the gel-filtration step of the purification. Both migrated as single polypeptides with $M_{\mathrm{r}}$ values of about $37 \times 10^{3}$ in SDS-PAGE (Fig. 3). This indicates that both enzymes are tetramers. LDH $_{L}$ moved slightly slower either because it is bigger (by about $2 \times 10^{3}$ ) or because of some other difference in primary structure. A mixture of the purified enzymes could be resolved by isoelectric focusing: $\mathrm{LDH}_{\mathrm{L}}$ focused at $\mathrm{pH} 5 \cdot 0$ and $\mathrm{LDH}_{\mathrm{E}}$ as a single band at $\mathrm{pH} 5 \cdot 2$ (not shown). This agrees with the behaviour during chromatofocusing. When the native purified enzymes were subjected to gel electrophoresis in the same conditions as used for crude extracts, $\mathrm{LDH}_{E}$ 


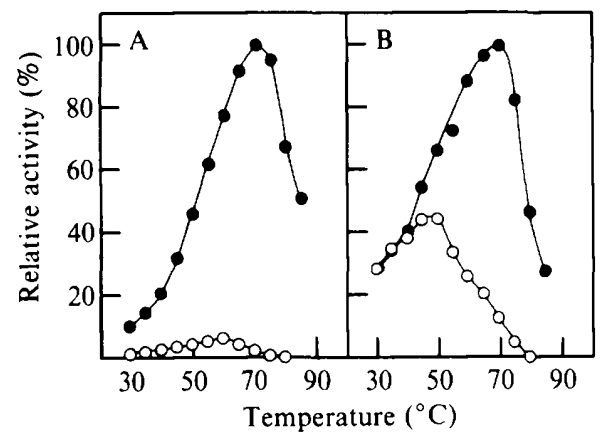

Fig 4. Effect of temperature on the activities of the $\mathrm{LDH}$ enzymes $\left(\mathrm{A}, \mathrm{LDH}_{E} ; \mathrm{B}, \mathrm{LDH}_{2}\right)$ in the presence and absence of $1 \mathrm{mM}-\mathrm{FBP}$. Reactions were started by addition of the purified enzymes (5$20 \mu \mathrm{l})$ to assay mixtures at the indicated temperatures with ()$\left.^{\circ}\right)$ and without $(O) 1 \mathrm{mM}-\mathrm{FBP}$.

travelled as a slow broad band corresponding to band (c) in Fig. 2 and $\mathrm{LDH}_{\mathrm{L}}$ as a faster sharper band corresponding to band $(a)$ in Fig. 2 (data not shown).

These large mobility differences suggested that although the two enzymes have similar pI and $M_{\mathrm{r}}$ values at room temperature and $\mathrm{pH} 6 \cdot 8$, their $M_{\mathrm{r}}$ values must differ under the conditions of the discontinuous electrophoresis, where the $\mathrm{pH}$ reaches 9.5 (Ornstein, 1964) during operation. Indeed, electrophoresis at $\mathrm{pH} 8.4$ through polyacrylamide gradients showed that $\mathrm{LDH}_{\mathrm{L}}$ dissociates, probably to a monomer (observed $M_{\mathrm{r}}<67 \times 10^{3}$ ), whereas $\mathrm{LDH}_{\mathrm{E}}$ migrated as at least three separate bands with apparent $M_{\mathrm{r}}$ values between 110 and $130 \times 10^{3}$ (not shown).

\section{General catalytic properties of the purified enzymes}

The optimum temperature for pyruvate reduction in the presence of FBP was $70^{\circ} \mathrm{C}$ for both enzymes (Fig. 4). The data in Fig. 4 are linear initial reaction rates, so the decreases in rate above $70^{\circ} \mathrm{C}$ appear to reflect real decreases in catalytic efficiency (rather than denaturation of the enzyme during measurement). $\mathrm{LDH}_{\mathrm{E}}$ was highly activated by $\mathrm{FBP}$ at all temperatures (from 7 fold at $30^{\circ} \mathrm{C}$ to 47 -fold at $70^{\circ} \mathrm{C}$ ). $\mathrm{LDH}_{\mathrm{L}}$ was activated by $\mathrm{FBP}$ only above $40^{\circ} \mathrm{C}$ ( 8 -fold at $70^{\circ} \mathrm{C}$ ). Because NADH became unstable at and above $70^{\circ} \mathrm{C}$ subsequent kinetic experiments were done at $65^{\circ} \mathrm{C}$, this being as close as was practical to the optimum growth temperature of $C$. thermohydrosulfuricum. No measurable decrease in absorbance at $340 \mathrm{~nm}$ was observed when NADPH was substituted for NADH at $65^{\circ} \mathrm{C}$. The $\mathrm{pH}$ dependence was determined in $100 \mathrm{~mm}$ sodium acetate/acetic acid ( $\mathrm{pH} 4 \cdot 0-6.0)$ and imidazole/ $\mathrm{HCl}\left(\mathrm{pH} \mathrm{6.0-8.0)} \mathrm{buffers} \mathrm{at} 65^{\circ} \mathrm{C}\right.$ in the presence of $1 \mathrm{~mm}-\mathrm{FBP}$ (data not shown). The $\mathrm{pH}$ optimum of both enzymes was at pH 5.5-6.0 and activity decreased rapidly on either side of the optimum. No activity was detectable at $\mathrm{pH} 8$ or above.

Although the oxidation of L-lactate could be demonstrated by the gel staining method with $\mathrm{LDH}_{\mathrm{L}}$, the reaction was too slow to be detected with either enzyme by spectrophotometric assay at $340 \mathrm{~nm}\left(50\right.$ or $\left.65^{\circ} \mathrm{C}\right)$.

Inorganic phosphate $\left(\mathrm{pH} 6.0\right.$ at $\left.65^{\circ} \mathrm{C}\right)$ had opposite effects on the two enzymes. It strongly activated $\mathrm{LDH}_{\mathrm{E}}$ in the absence of FBP (activations of 2-, 8- and 15-fold at 25, 100 and $200 \mathrm{mM}$ sodium phosphate), but had no effect in the presence of $1 \mathrm{mM}$-FBP. However, at concentrations up to $80 \mathrm{mM}$ it increasingly inhibited $\mathrm{LDH}_{\mathrm{L}}$ both in the presence $(80 \%$ inhibition) and absence ( $55 \%$ inhibition) of FBP; between $80 \mathrm{~mm}$ and $200 \mathrm{~mm}$ the activity was partially restored. Similar concentrations of $\mathrm{NaCl}$ caused inhibition (reaching about $40 \%$ at $250 \mathrm{mM}-\mathrm{NaCl}$ ) of both enzymes in both the presence and absence of FBP, suggesting that the activations by sodium phosphate are specific effects.

\section{Dependence of catalytic activity on FBP and substrate concentrations}

At pH 6.0 and $65^{\circ} \mathrm{C}$ and high pyruvate $(10 \mathrm{mM})$ and NADH $(0.25 \mathrm{~mm})$ concentrations the rate of $\mathrm{LDH}_{\mathrm{E}}$ activity was increased 22 -fold with a half-maximum effect at $12 \mu \mathrm{M}-\mathrm{FBP}$, whereas 


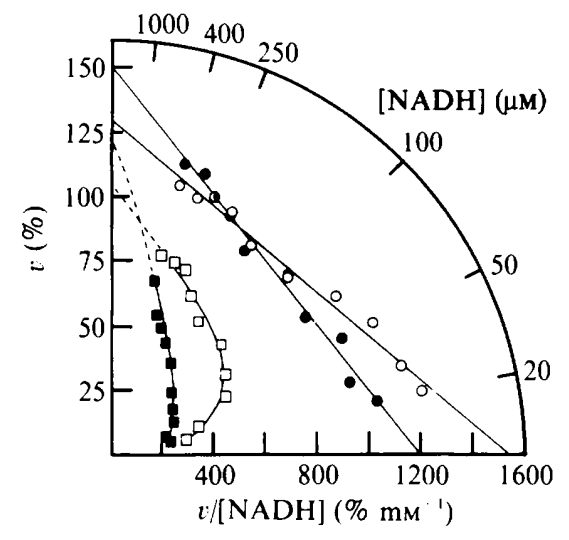

Fig. 5

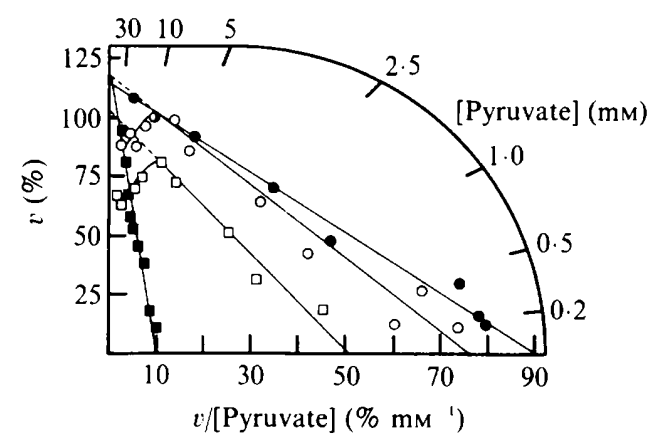

Fig. 6

Fig. 5. Dependence of catalytic activity on $\mathrm{NADH}$ at $65^{\circ} \mathrm{C}, \mathrm{pH} 6.0$. Activities of $\mathrm{LDH}_{\mathrm{E}}$ (open symbols) and $\mathrm{LDH}_{\mathrm{L}}$ (closed symbols) were measured as described in Methods at $10 \mathrm{mM}$-pyruvate and either $1 \mathrm{~mm}(O, O)$ or $0.05 \mathrm{mM}(\square, \square)$ FBP. The NADH concentration was varied between 20 and $250 \mu \mathrm{M}$ (NADH concentration can be obtained by joining the markers on the curved scale to the origin with a straight edge). For each enzyme the initial velocity $(v)$ was set to be $100 \%$ at $250 \mu \mathrm{M}-\mathrm{NADH}$ and $1 \mathrm{mM}-\mathrm{FBP}$.

Fig. 6. Dependence of catalytic activity on pyruvate at $65^{\circ} \mathrm{C}, \mathrm{pH} 6.0$. Activities of $\mathrm{LDH}_{\mathrm{E}}$ (open symbols) and $\mathrm{LDH}_{\mathrm{L}}$ (closed symbols) were measured as described in Methods at $250 \mu \mathrm{M}-\mathrm{NADH}$ and either $1 \mathrm{~mm}(\mathrm{O}, \mathrm{O})$ or $0.05 \mathrm{mM}(\square, \square)$ FBP. The pyruvate concentration was varied between $0 \cdot 15$ and $30 \mathrm{~mm}$ (the curved pyruvate scale is read as described in Fig. 5). For each enzyme the initial velocity $(v)$ was set to be $100 \%$ at $10 \mathrm{~mm}$-pyruvate and $1 \mathrm{mM}-\mathrm{FBP}$.

$\mathrm{LDH}_{\mathrm{L}}$ was insensitive up to $10 \mu \mathrm{M}-\mathrm{FBP}$ and then showed a 4 -fold increase in rate with a halfmaximum effect at $80 \mu \mathrm{M}-\mathrm{FBP}$ (not shown). Experiments with crude extracts of starch-grown cells at $0.25 \mathrm{~mm}-\mathrm{NADH}$ and $40^{\circ} \mathrm{C}$ showed that the FBP requirement of $\mathrm{LDH}_{\mathrm{E}}$ was greatly dependent on both $\mathrm{pH}$ and pyruvate concentration. In these conditions, the concentrations of FBP needed for half-maximum stimulation at $10 \mathrm{mM}$ - and $1 \mathrm{mM}$-pyruvate, respectively, were $3 \mu \mathrm{M}$ and $20 \mu \mathrm{M}$ at $\mathrm{pH} 6 \cdot 0$ but $40 \mu \mathrm{M}$ and $260 \mu \mathrm{M}$ at $\mathrm{pH} 7 \cdot 0$.

$\mathrm{NADH}$ dependence at $10 \mathrm{~mm}$-pyruvate is shown in Fig 5. At a saturating FBP concentration $(1 \mathrm{mM})$ the enzymes had similar apparent $K_{\mathrm{m}}$ values $\left(\mathrm{LDH}_{\mathrm{E}} 80 \mu \mathrm{M} ; \mathrm{LDH}_{\mathrm{L}} 130 \mu \mathrm{M}\right)$. At a lower FBP concentration $(0.05 \mathrm{mM})$ both enzymes showed a positively co-operative dependence on $\mathrm{NADH}$, but this co-operativity was strong for $\mathrm{LDH}_{\mathrm{E}}$ and weak for $\mathrm{LDH}_{\mathrm{L}} . V_{\max }$ values could not be accurately estimated because of problems in measuring rates above $0.4 \mathrm{mM}-\mathrm{NADH}$, but reasonable extrapolations (broken lines in Fig. 5) suggest that decreasing the FBP concentration also decreased the apparent $V_{\max }$ values.

Pyruvate dependence at $0.25 \mathrm{~mm}-\mathrm{NADH}$ is shown in Fig 6. At $1 \mathrm{~mm}-\mathrm{FBP}$ the enzymes had similar $K_{\mathrm{m}}$ values $\left(\mathrm{LDH}_{\mathrm{E}} 1.5 \mathrm{mM} ; \mathrm{LDH}_{\mathrm{L}} 1.3 \mathrm{~mm}\right)$. Decreasing the FBP concentration to $0.05 \mathrm{~mm}$ increased the apparent $K_{\mathrm{m}}$ for $\mathrm{LDH}_{\mathrm{L}}$ by 10 -fold to $12 \mathrm{mM}$ with little or no decrease in $V_{\max }$. For $\mathrm{LDH}_{\mathrm{E}}$ the apparent $K_{\mathrm{m}}$ for pyruvate at $0.05 \mathrm{~mm}-\mathrm{FBP}$ was still similar $(2 \mathrm{mM})$ to that observed at $1 \mathrm{mM}$-FBP, and $V_{\max }$ was only slightly smaller. No evidence for co-operative dependence on pyruvate was found for either enzyme. However, concentrations of pyruvate between 10 and $30 \mathrm{~mm}$ caused a marked substrate inhibition of $\mathrm{LDH}_{\mathrm{E}}$ but not $\mathrm{LDH}_{\mathrm{L}}$.

The following sugar phosphates were tested with pure enzymes at $65^{\circ} \mathrm{C}$ for the ability to substitute for FBP: mannose 6-phosphate, glucose 1-phosphate, glucose 6-phosphate, glucose 1,6-bisphosphate, fructose 1-phosphate and fructose 6-phosphate. Only glucose 1,6-bisphosphate activated $\mathrm{LDH}_{\mathrm{E}}$; at $1 \mathrm{mM}$ it gave $55 \%$ of the activity obtained with FBP. Neither glucose 1,6-bisphosphate nor the other sugar phosphates tested had any effect on the $\mathrm{LDH}_{\mathrm{L}}$ activity. 


\section{DISCUSSION}

Lactic acid production by $C$. thermohydrosulfuricum increases at the expense of ethanol production when the initial concentration of glucose or starch is increased (Parkkinen, 1986; unpublished observations cited by Germain $e t$ al., 1986). So far, however, we have found yields of lactic acid to approach the theoretical maximum only in certain fermentations with sucrose as carbon source. Several authors (e.g., Hyun et al., 1985; Germain et al., 1986) have investigated the enzymes catabolizing pyruvate in $C$. thermohydrosulfuricum with a view to understanding how the balance between ethanol and lactic acid is controlled. Our results (Fig. 1) are consistent with the notion that the production of lactic acid rather than ethanol in some sucrose fermentations is caused by a large increase in the amount of LDH in the cells. We also found that $\mathrm{NADP}^{+}$-dependent $\mathrm{ADH}^{-}$levels were drastically lower in cells producing lactic acid than in cells producing ethanol. The metabolic roles of the $\mathrm{NAD}^{+}$- and NADP+-linked ADHs in $C$. thermohydrosulfuricum are not understood. The NADP+-linked ADH is reversible (Lamed \& Zeikus, 1981) and so might operate in vivo to produce ethanol provided that NADPH can be regenerated. In this case, the smaller amount of this enzyme in cells producing lactate may also have contributed to their decreased formation of ethanol. Unlike Hyun et al. (1985), we were unable to detect $\mathrm{NADP}^{+}$-dependent $\mathrm{LDH}$ in $C$. thermohydrosulfuricum, at least not in aerobic assay conditions. The cause of this discrepancy is not known. Hyun et al. (1985) used a different bacterial strain (39E) and anaerobic assay conditions.

Our results suggest that distinct isoenzymes of $\mathrm{LDH}, \mathrm{LDH}_{\mathrm{E}}$ and $\mathrm{LDH}_{\mathrm{L}}$ respectively, are present in cells producing mainly ethanol or mainly lactic acid. They may be products of different genes or be related by post-translational modifications, such as proteolysis or phosphorylation. $\mathrm{LDH}_{\mathrm{E}}$ dissociates less readily than $\mathrm{LDH}_{\mathrm{L}}$ into subunits (see Results), which may be connected with the differences in catalytic properties, as seems to be the case with LDH from Streptococcus uberis (Williams \& Andrews, 1986). C. thermohydrosulfuricum is a thermophilic bacterium able to grow at temperatures between 40 and $78{ }^{\circ} \mathrm{C}$, with an optimum at $68^{\circ} \mathrm{C}$ (Wiegel et al., 1979). Fig. 4 emphasizes the importance of measuring the catalytic properties of its enzymes at physiological temperatures. At $40{ }^{\circ} \mathrm{C}$ only $\mathrm{LDH}_{E}$ was activated by FBP. However, both isoenzymes showed a true temperature optimum at about $70{ }^{\circ} \mathrm{C}$ in the presence of 1 mM-FBP. The degree of activation (47-fold for $\mathrm{LDH}_{\mathrm{E}}$ and 8-fold for $\mathrm{LDH}_{\mathrm{L}}$ at $10 \mathrm{~mm}$-pyruvate and $0.25 \mathrm{~mm}-\mathrm{NADH})$ is much higher than that $(1.4$-fold at $8 \mathrm{~mm}$-pyruvate and $0.1 \mathrm{mM}-\mathrm{NADH}$ ) reported by Germain et al. (1986) at an unknown temperature and in $0.1 \mathrm{M}-$ phosphate, $\mathrm{pH}$ 6.9. The use of phosphate may have contributed to the low degree of activation observed by these authors, because at $65^{\circ} \mathrm{C} 0.1 \mathrm{M}$-phosphate inhibited $\mathrm{LDH}_{\mathrm{L}}$, activated $\mathrm{LDH}_{\mathrm{E}}$ and decreased the response of both enzymes to FBP (see Results). The ability of phosphate to inhibit $\mathrm{LDH}_{\mathrm{L}}$ and to mimic the activation of $\mathrm{LDH}_{\mathrm{E}}$ by $\mathrm{FBP}$ is interesting, because high yields of lactic acid are never obtained in fermentations of sucrose in media containing $0.1 \mathrm{M}$-phosphate (Parkkinen \& Turunen, 1986). Which isoenzyme is present in these cells and the intracellular concentration of phosphate are not known. Intracellular phosphate can reach $75 \mathrm{~mm}$ in Streptococcus faecalis (Harold \& Spitz, 1975). The strong activation of $\mathrm{LDH}_{\mathrm{E}}$ by phosphate is unusual (see Garvie, 1980). More commonly the FBP-dependent enzymes such as that from Lactobacillus casei (Holland \& Pritchard, 1975; Gordon \& Doelle, 1976) are inhibited.

In agreement with studies on crude enzyme by Germain et al. (1986), we found that increasing the concentration of FBP decreased the $K_{\mathrm{m}}$ for pyruvate, greatly for $\mathrm{LDH}_{\mathrm{L}}$ and slightly for $\mathrm{LDH}_{\mathrm{E}}$ (Fig. 6), and increased the affinity of both isozymes for NADH. However, the dependence on NADH became positively co-operative at the lower FBP concentration. In common with the most FBP-dependent LDHs (Garvie, 1980) both isoenzymes had a high specificity for FBP. However, glucose 1,6-bisphosphate activated $\mathrm{LDH}_{\mathrm{E}}$, as has also been shown for the enzyme from Streptococcus cremoris (Thomas, 1975).

The physiological significance of the effects of FBP is difficult to assess. Our results imply that $\mathrm{LDH}_{\mathrm{E}}$ and $\mathrm{LDH}_{\mathrm{L}}$ would both be saturated at the intracellular concentrations of FBP [1.7 to $\left.13.4 \mu \mathrm{mol}(\mathrm{g} \text { dry wt })^{-1}\right]$ reported by Germain et al. (1986). We have found somewhat smaller FBP concentrations [between 2 and $<0.04 \mu \mathrm{mol}$ ( $\mathrm{g}$ fresh wt $)^{-1}$ ] but they did not correlate with lactic acid production (M. Turunen, unpublished results). Also, at least at $40^{\circ} \mathrm{C}$ the 
concentration of FBP required for half-maximum activation was higher at $\mathrm{pH} 7.0$ than $\mathrm{pH} 6.0$ and higher at $1 \mathrm{~mm}$-pyruvate than at $10 \mathrm{~mm}$-pyruvate. Clearly, accurate information about intracellular $\mathrm{pH}$ and metabolite concentrations is needed before the kinetic data for LDH can be fully interpreted.

\section{REFERENCES}

BRADFORD, M. M. (1976). A rapid and sensitive method for the quantitation of microgram quantities of protein utilizing the principle of protein dye binding. Analytical Biochemistry 72, 248-254.

Carreira, L. H., Wiegel, J. \& Ljungdahl, L. G. (1983). Production of ethanol from biopolymers by anaerobic, thermophilic and extreme thermophilic bacteria: I. regulation of carbohydrate utilization in mutants of Thermoanaerobium ethanolicus. In Biotechnology and Bioengineering Symposium 13, pp. 183-191. Edited by C. D. Scott. New York: John Wiley.

Davis, B. J. (1964). Disc electrophoresis. II. Method and application to human serum proteins. Annals of the New York Academy of Sciences 121, 404-427.

GARVIE, E. I. (1969). Lactic dehydrogenases of strains of the genus Leuconostoc. Journal of General Microbiology 58, 85-94.

GARVIE, E. I. (1980). Bacterial lactate dehydrogenases. Microbiological Reviews 44, 106-139.

Geirmain, P., Toukourou, F. \& Donaduzzi, L. (1986). Ethanol production by anaerobic thermophil.c bacteria: regulation of lactate dehydrogenase activity in Clostridium thermohydrosulfuricum. Applied Microbiology and Biotechnology 24, 300-305.

Gordon, G. L. \& Doelle, H. W. (1976). Purification, properties and immunological relationship of $L(+)$ lactate dehydrogenase from Lactobacillus casei. European Journal of Biochemistry 67, 543-555.

HAROLD, F. M. \& SPITZ, E. (1975). Accumulation of arsenate, phosphate, and aspartate by Streptococcus faecalis. Journal of Bacteriology 122, 266-277.

Holland, R. \& Pritchard, G. G. (1975). Regulation of the L-lactate dehydrogenase from Lactobacillus casei by fructose 1,6-diphosphate and metal ions. Journal of Bacteriology 121, 777-784.

Hyun, H. H., Shen, G.-J. \& Zeikus, J. G. (1985). Differential amylosaccharide metabolism of Clostridium thermosulfurogenes and Clostridium thermohydrosulfuricum. Journal of Bacteriology 164, 11531161.

LAEMMLI, U.K. (1970). Cleavage of structural proteins during the assembly of the head of bacteriophage T4. Nature, London 227, 680-685.

LAMED, R. \& ZeIKus, J. G. (1980). Glucose fermentation pathway of Thermoanaerobium brockii. Journal of Bacteriology 141, 1251-1257.

LAMED, R. J. \& Zeikus, J. G. (1981). Novel NADPlinked alcohol-aldehyde/ketone oxidoreductase in thermophilic ethanologenic bacteria. Biochemical Journal 195, 183-190.

ORNSTEIN, L. (1964). Disc electrophoresis. I. Background and theory. Annals of the New York Academy of Sciences 121, 321-349.

PARKKINEN, E. (1986). Conversion of starch into ethanol by Clostridium thermohydrosulfuricum. Applied Microbiology and Biotechnology 25, 213-219.

ParkKinen, E. \& Korhola, M. (1984). Starch fermentation by Clostridium thermohydrosulfuricum. In Third European Congress on Biotechnology, vol. II, pp. 223-230. Weinheim: Verlag Chemie.

PARKKINEN, E. \& TURUNEN, M. (1986). Fermentation of sucrose by Clostridium thermohydrosulfuricum. In Abstracts of the 14 th International Congress of Microbiology ('Microbe 86') (September 1986, Manchester, UK), p. 204.

Thomas, T. D. (1975). Tagatose 1,6-diphosphate activation of lactate dehydrogenase from Streptococcus cremoris. Biochemical and Biophysical Research Communications 63, 1035-1042.

Wiegel, J., LuUNGDAHL, L. G. \& Rawson, J. R. (1979). Isolation from soil and properties of the extreme thermophile Clostridium thermohydrosulfuricum. Journal of Bacteriology 139, 800-810.

Williams, R. A. \& ANDREWS, P. (1986). Purification of the fructose 1,6-bisphosphate-dependent lactate dehydrogenase from Streptococcus uberis and an investigation of its existence in different forms. Biochemical Journal 236, 721-727.

Zeikus, J. G., Ben-Bassat, A. \& Lamed, R. J. (1981). Thermophilic ethanol fermentations. In Trends in the Biology of Fermentations in Fuels and Chemicals, pp. 441-461. Edited by A. Hollander. New York: Plenum Press. 